\title{
THE FITNESS OF COPINGS CONSTRUCTED OVER UCLA ABUTMENTS AND THE IMPLANT, CONSTRUCTED BY DIFFERENT TECHNIQUES: CASTING AND CASTING WITH LASER WELDING
}

\author{
ADAPTAÇÃO DE COPINGS DE TITÂNIO AO IMPLANTE , CONSTRUÍDOS SOBRE PILARES \\ UCLA POR DUAS TÉCNICAS: FUNDIÇÃO E FUNDIÇÃO COM SOLDAGEM DE BORDO LASER
}

Elza Maria Valadares da COSTA ${ }^{1}$, Luciana Satie HOÇOYA², Marco Antônio BOTTINO ${ }^{1}$

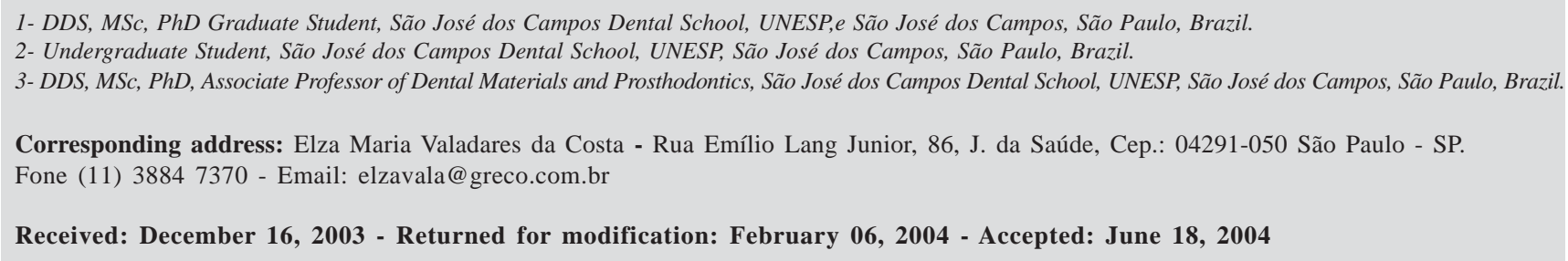

\begin{abstract}
7

1 he alternative for the reposition of a missing tooth is the osteointegrated implant being the passive adaptation between the prosthodontic structure and the implant a significant factor for the success of this experiment, a comparative study was done between the two methods for confectioning a single prosthodontic supported by an implant. To do so a screwed implant with a diameter of $3.75 \mathrm{~mm}$ and a length of $10.0 \mathrm{~mm}$ (3i Implant innovations, Brasil) was positioned in the middle of a resin block and over it we screwed 15 UCLA abutments shaped and antirotationable (137CNB, Conexão Sistemas de Próteses, Brasil) with a torque of 20N.cm without any laboratorial procedure (control group CTRLG). From a silicon model 15 UCLA-type calcinatable compounds (56CNB, Conexão Sistemas de Próteses, Brasil) were screwed (20 N.cm), received a standard waxing (plain buccal surface) and were cast in titanium (casting group - CG) and other 15 compounds, UCLA - type shaped in titanium (137 CNB, Conexão Sistemas de Próteses, Brasil) received the same standard waxing. These last copings were cast in titanium separated from each other and were laser-welded to the respective abutments on their border (Laser-welding group - LWG). The border adaptation was observed in the implant/compound interface, under measurement microscope, on the y axis, in 4 vestibular, lingual, mesial and distal referential points previously marked on the block. The arithmetical means were obtained and an exploratory data analysis was performed to determine the most appropriate statistical test. Descriptive statistics data $(\mu \mathrm{m})$ for Control (mean \pm standard deviation: $13.50 \pm 21.80$; median 0.00), for Casting (36.20 \pm 12.60 ; 37.00), for Laser $(10.50 \pm 12.90$; 3.00) were submitted to Kruskal-Wallis ANOVA, $\alpha=5 \%$. Results test showed that distorsion median values differ statistically $(\mathrm{kw}=17.40 ; \mathrm{df}=2 ; \mathrm{p}=0.001<0.05)$. Dunn's $(5 \%)$ test show difference between Casting and the two others. Conclusion: on the y axis, the smallest distortion values were obtained by the laser welding group.

Uniterms: Titanium; Dental implant; Laser welding.
\end{abstract}

\begin{abstract}
RESUMO
A reposição de um elemento dentário pode ser feita por um implante osseointegrado sendo que a adaptação passiva de sua estrutura protética é um fator relevante para o sucesso deste trabalho. Um estudo comparativo foi feito entre dois métodos de confecção de prótese unitária suportada por implante. Para tanto incluímos no centro de um bloco de resina um implante rosqueado de $3.75 \mathrm{~mm}$ de diâmetro por $10.0 \mathrm{~mm}$ de comprimento (3i Implant innovations, Brasil) e sobre este parafusamos com torque de 20N.cm 15 pilares UCLA torneados anti-rotacionais (137CNB, Conexão Sistemas de Próteses, Brasil) sem qualquer procedimento laboratorial (grupo controle - GC). A partir de um molde de silicone, 15 componentes tipo UCLA calcináveis (56CNB, Conexão Sistemas de Próteses, Brasil) foi parafusado (20N.cm) ao implante e receberam enceramentos padrão (face vestibular plana) os quais foram fundidos em titânio (grupo fundição - GF). 15 componentes, tipo UCLA torneados em titânio (137CNB, Conexão, Sistemas de Próteses, Brasil) receberam o mesmo enceramento padrão e estes copings foram fundidos em titânio separados e soldados a laser aos respectivos pilares em seu bordo (grupo soldagem a laser- GSL). A adaptação marginal foi observada na interface implante/componente, sob microscópio de medição, no eixo y, em 4 pontos de referência na vestibular, lingual, mesial e distal previamente marcados no bloco. As médias aritméticas foram obtidas e uma análise dos dados foi feita para determinar o teste estatístico mais apropriado. Os dados estatísticos descritivos $(\mu \mathrm{m})$ para Controle (média \pm desvio padrão:13.50 \pm 21.80; mediana 0.00), for Fundição (36.20 \pm 12.60 ; 37.00), para Laser (10.50 \pm 12.90 ; 3.00$)$ foram submetidos ao Kruskal-Wallis ANOVA, $\alpha=5 \%$. Resultados: Os testes mostraram que os valores médios de distorção diferem estatisticamente $(\mathrm{kw}=17.40 ; \mathrm{df}=2 ; \mathrm{p}=0.001<0.05)$. O teste Dunn's $(5 \%)$ mostra diferença entre Fundição e os outros dois grupos. Conclusão: No eixo y, os menores valores de distorção foram obtidos pelo grupo soldagem a laser de bordo (GSL).

Unitermos: Titânio; Implante dentário;Soldagem.
\end{abstract}




\section{INTRODUCTION}

One option for oral reabilitation when a single tooth is missing (for caries, periodontal problems, trauma, orthodontical indication or congenital defects) is the osseointegrated implant.

The term osseointegration refers to the direct contact between the bone and the implant, that is screw-shaped providing a larger contact area and a better distribution for the oclusal charges that act on the interface $e^{2,5,9,10}$. In this system, it is desired that the force is on the longitudinal implant axis, distributing the tensions proportionally, these being normally absorbed by the bone and the implant. If this axial axis is not followed, moments of flexion can occur, that is, there will be a force concentration in one area of the bone what may cause a harmful stress for both ${ }^{11}$.

Aiming to avoid those problems such as the undesired force concentration, the implant must have a relevant characteristic: the passive adaptation. Such a level of fit is referred to as "passive" inthe sense that after conection of the prosthesis, the implant position remains undisturbed from the prefastened state ${ }^{5,10}$. Through scanning electron microscopy this adaptation can be analyzed, if it is ideal or if there are gaps between the prosthodontic and the abutment.

Emphasis is given to the passive adaptation since, its absence can cause problems to the adjacent biological structures (tissue reaction, mucositis, periimplantitis and bone remodeling); loosening of the screws (the prosthodontic crown can become loose and the function and aesthetics of the patient can get compromised), mobility due to transverse stress; and when the screws are repeatedly and exaggeratedly tightened, fatigue can occur and cause a fracture of the implant components $2,6,9,10,11$.

The instability of the prosthodontic structure and of the intermediate is a consequence of the non-passive cast pieces and of the unbalanced occlusal forces (compressive and tension), because these cause vibration and loosening. It can be concluded that the larger the adaptation, the larger will be the longevity and the better will be the functioning of all the biomechanical system.

In addition, tough, several factors can induce distortion; the sum of insignificant failures on the many steps of the prosthodontic confection, from the first casting to the placing of the final prosthodontic piece, can lead to a misadaptation $^{6,15}$.

It is known that the implant components, specifically the titanium cylinder and the intermediate, have a precise adaptation since they are products resulting of computerized lathes ${ }^{6}$. The causes of distortions are the chosen methods for specific phases. And one disturbing phase is the cast.

In single implants, the coping can be obtained from teflon abutments, cast in titanium and screwed to the implant directly, another option would be the casting the coping separately and then welded to the pre-fabricated titanium abutment (border laser welding) and as the previous one, screwed directly to the implant. Nevertheless, we didn't find on the literature experiments concerning single implants, related to these possible techniques.

It must be analyzed which is the best method to achieve a minimization of the alterations on the moment of the components attachment and obtain the best possible adaptation.

According to $\mathrm{Goll}^{7}$, occurring from the several prosthetic steps in which the implant components are involved, the probability of a distortion to happen is big. This author addes that the complexity of these procedures give place to the presence of failures. Tough, nowadays there are devices and materials that help us to minize the nocive effects. The cast is one phase that must be done carefuly, because this can set the durability of the components and alterations of the properties of the materials.

Sakaguchi and Borgersen ${ }^{13}$, performed a research aiming to verify the reasons that take the implant to fatigue and failure. As an answer, they obtained that the continuous lateral translation cycles lead to a loosen and fracture of the components, that is, when the forces received by the crown are not directed to the longitudinal axis of the implant, there is a lost of adaptation of the gold cylinder to the intermediate or of the crown to the intermediate leading even to a deformity of these.

Jemt and Pettersson ${ }^{8}$ verified that the loosen of the screw was present in a big part of the patients. In the present study they noticed that $44,9 \%$ had to tighten their components at least once during the following three years. Associated to this problem, the presence of fistula as a consequence to the mechanical instability and inflammation of the periodontal tissues resulting mainly from poor hygiene was frequent. Still regarding the periodontal tissues, a reduction of even $0,5 \mathrm{~mm}$ at the bone crest level was observed in the first year, and in the following years this reduction rate tended to stabilization.

According to Yamagishi, et al. ${ }^{16}$, in 1993, laser welding promotes a better connection for it results from the fusion of the metal itself, without the use of addition material. The authors mentioned that laser welding produces a coherent, monochromatic and concentrated high-energy ligth beam that has been used to replace brazing in dental prosthesis.

Cordioli, et al. ${ }^{5}$ confirmed the success that can be achieved when single implants are used. Tough, due to difficulties of hygiene showed by part of the patients, irritations related to the periodontal tissues could be notified. A percentage of these showed bleeding to probing (43,7\%), but as to bone loss (average of $0,3 \mathrm{~mm}$ ) this manifested mainly in the first year, becoming stable afterwards.

Waskewicz, et al. ${ }^{14}$ analyzed the amount of stress received by the bone during the tighten of adapted pieces, in a passive or non-passive way, when submitted to a torque of $10 \mathrm{~N} / \mathrm{cm}^{2}$. As a result, they showed that the screwing of an adapted piece in a non-passive way generates a force concentration around the implant, but when the relation was passive these signals were not present.

Berg, et al. ${ }^{1}$, in 1995, made a study comparing one prosthodontic titanium cast in monoblock and another submitted to casting in segments and laser welding. The control group was composed by gold cylinders that casting. 
The titanium frame welded by laser presented as being more resistant than the gold that suffered casting, but both techniques lead to a significant reduction on the ductility of the metals.

Riedy, et al. ${ }^{12}$ compared two techniques used in the union of the implant components: laser welding and single block casting. They found out that the laser welded components showed a better adaptation when compared to the single block cast. In the first technique the misadaptation was lesser than $25 \mu \mathrm{m}$.

Costa ${ }^{3}$ performed a study about the evaluation of the linear distortion in metallic structures of prosthodontics over implants, cast in a single piece and in segments welded by laser and through the conventional welding (brasing). It was discussed the viability of the laser welding technique substituting other ones, mainly in a prosthesis over multiple implants, where it is difficult to obtain a passive fit.

As seen before, there are several techniques available to perform each step of the rehabilitation and if there are failures these will sum up and at the end of the work we will have an implant without adaptation. So, it's up to the professional to choose the best method for each clinical situation with the objective of achieving the best functional and aesthetical result to the patient.

The relationship of the prosthodontical components in the construction of single crowns of osseointegrated implants is important to the integrity of the adjacent biological structures. This study intends to compare the casting of calcinatable abutments UCLA-type in titanium and separated casting with later border laser welding to abutments UCLA-type machined in titanium.

\section{MATERIALAND METHOD}

It was included, in the middle of a transparent resin block, a screwed implant with a diameter of $3.75 \mathrm{~mm}$ and $10 \mathrm{~mm}$ length ( $3 \mathrm{i}$ Implants Innovations Brazil) . Only its retentive part remained within the resin, to easy the visualization the border adaptation to the coping (Figure 1). This quadrangular block $(2,5 \mathrm{~cm}$ width for $3,0 \mathrm{~cm}$ height) shows its four plain surfaces marked with the letters V (vestibular), L (lingual), $\mathrm{M}$ (mesial) and D (distal). The occlusal surface of this model has two perpendicular lines with an intersection that coincides with the center of the implant. These two lines also coincides with the middle of the 4 axial surfaces. These lines were made so it could be performed the observation of the adaptation copings always in the center of the vestibular, lingual, mesial and distal surfaces.

\section{Making of the pattern structure in wax (samples)}

To standardization, a waxing simulating a coping with one of the faces plain (vestibular) was performed over a UCLA titanium abutment, anti-rotation, indicated for single implants (code 137 CNB, Conexão Sistemas de Próteses, Brasil) which was molded with adding silicon (Express 3M). This model was used to obtain a pattern to provide 30 identical waxing (Figure 2).

In the laser welding group (LWG) the waxing standardized by this method were performed over 15 UCLA titanium anti-rotation abutments (code 137CNB, Conexão Sistemas de Próteses, Brasil) and in the casting group (CG) over 15 abutments UCLA Teflon calcinatable cast nonrotational (56 CNB, Conexão Sistemas de Prótese, Brazil).

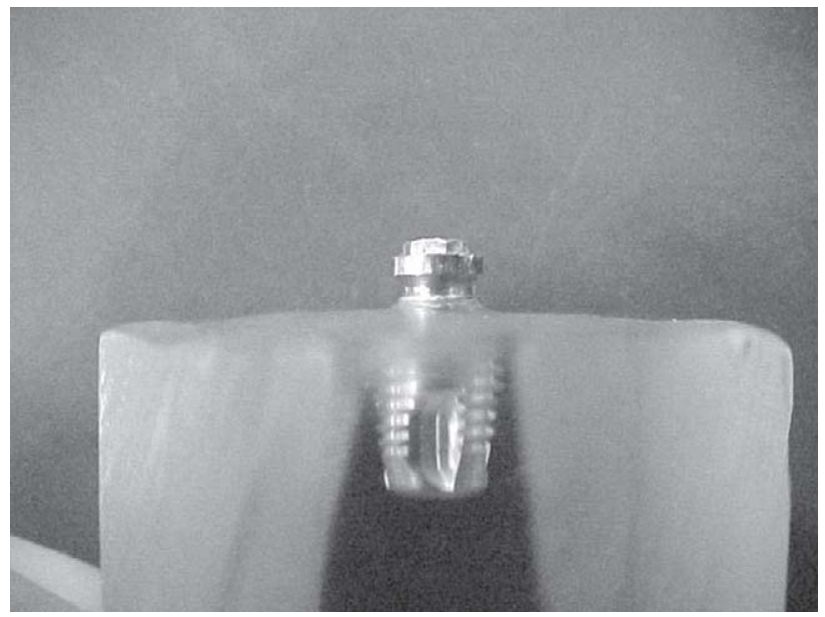

FIGURE 1- transparent resin block with implant

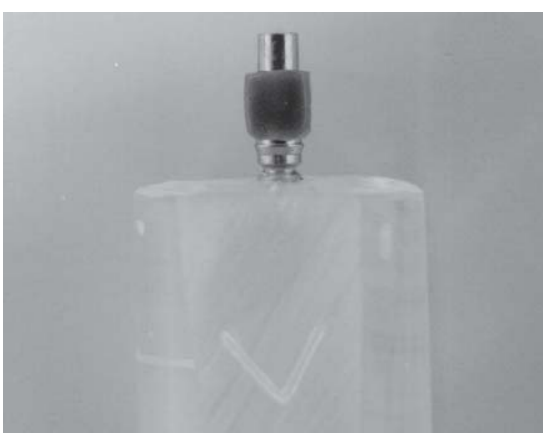

a

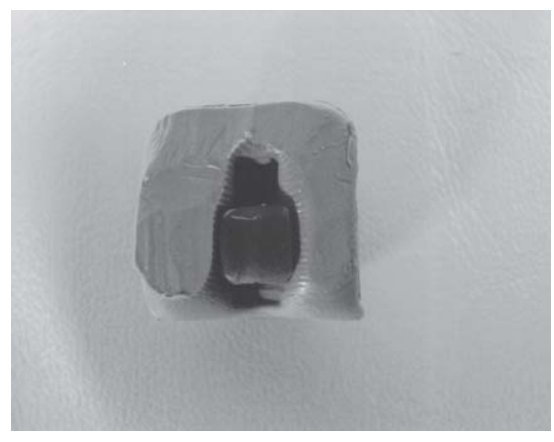

b

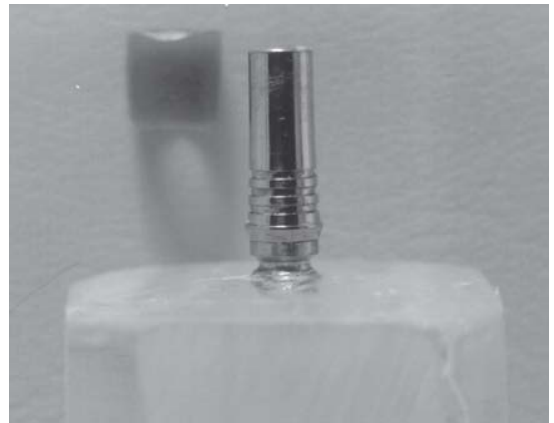

C

FIGURE 2- (a) standard waxing in position over titanium UCLA, (b) silicon pattern and (c) UCLA and waxing of laser welding group 


\section{Casting: Laser welding group (LWG)}

On the implant, it was connected 15 titanium abutments with a torque of $20 \mathrm{~N} . \mathrm{cm}$ and over these it was positioned the standard waxing as described before. After that, 5 copings per wax ring were included within $200 \mathrm{~g}$ of the appropriate coating (Rematitan plus - Dentaurum Hülls Germany) and cast separately in titanium cp (Tritan Dentaurum J.P. Winkelstroeter KG- Pforzheim - Germany).

The casting was made in a vacuum machine (Dentaurum rematitan, Germany) in the presence of Argon gas at a power of $330 \mathrm{~J}$ and a laser pulse of $9.0 \mathrm{~ms}$. This machine shows two vaults linked by an opening: one upper, where a pastille of the used alloy was placed, being the casting performed through a voltaic arch system and one lower, where the coating model was placed. At the casting moment the upper vault was filled with argon gas, whereas the lower vault was submitted to vacuum. After the casting, the coating was immediately put under water, according to the manufacturer's specifications. After the complete cooling, the coating was fractured, performing a jet of aluminum oxide of $110 \mu \mathrm{m}$ on the casting. So, the feeding conducts were cut with a carborundum disc.

After the casting, these copings were put together with a laser welding to the titanium abutment on its upper and lower borders. The same number of welding points was kept all over the coping border, and the same welding energy was used for all the 15 cylinders. The union was made on the laser welding device (Dentaurum, DI 2002 S/SFS, model Desktop, Germany). The procedure recommended by the manufacturer was followed to the welding of the borders of this group 15 samples (Figure 3a).

\section{Group C (CASTING)}

15 UCLA-type calcinatable teflon abutments (056 CNB, Conexão Sistemas de Próteses, Brasil) were connected with a torque of 20 N.cm to the implant. They were included in the center of the resin block and over these 15 standard waxing were confected. Then, they were casted together (waxing plus the abutment), with the same alloy following the identical protocol of casting previously used for the laser welding group (LWG) (Figure 3b).

\section{Control Group}

This group was composed only by the 15 UCLA shaped titanium abutments (code $137 \mathrm{CNB}$, Conexão Sistemas de Próteses, Brasil) connected to the implant with UCLA hexagonal titanium screws (MS3, 75/4, 119CNB, Conexão Sistemas de Prótese, Brazil) with a torque 20 N.cm, without any laboratorial procedure.

\section{Analysis of marginal Adaptation and passivity}

The samples of the 3 groups (CTRLG, LWG and CG) analyzed were connected to implant with a preconized torque of $20 \mathrm{~N} . \mathrm{cm}$. The readings of the values of the gap, representing the level of adaptation between the copings and the implant (LWG e CG) and between the UCLA abutments and implant (CTRLG) were done by a measurement microscope (Olympus STM, Japan). This microscope presents a magnifying of 30x (10x on the ocular and $3 x$ on the objective), with a precision of $0,5 \mu \mathrm{m}(0,0005$ $\mathrm{mm}$ ) and an auxiliary reading unit (MMDC 201 for the $y$ axis analyzed).

The marginal adaptation was observed in reference points in the center of the faces vestibular and lingual, mesial and distal previously marked on the resin block that contains the implant. The observations of the gaps in four referents points were done for each sample, all registered in micrometers, on the y axis.

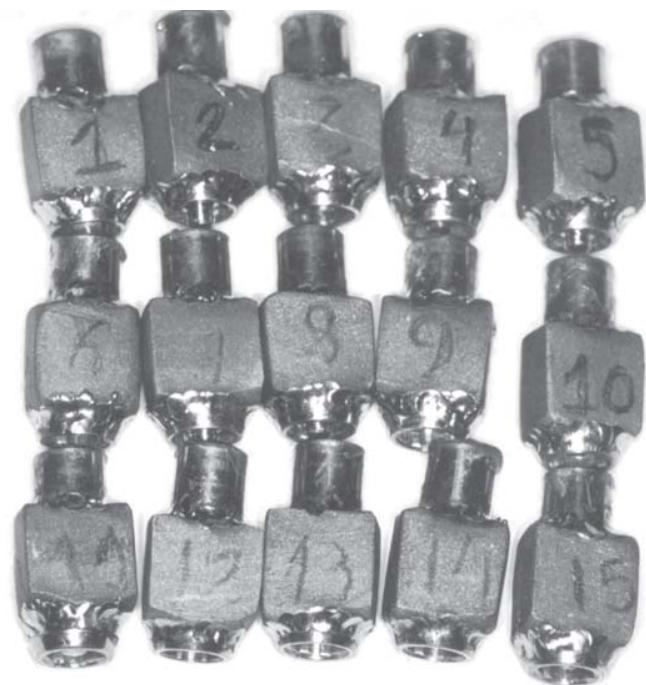

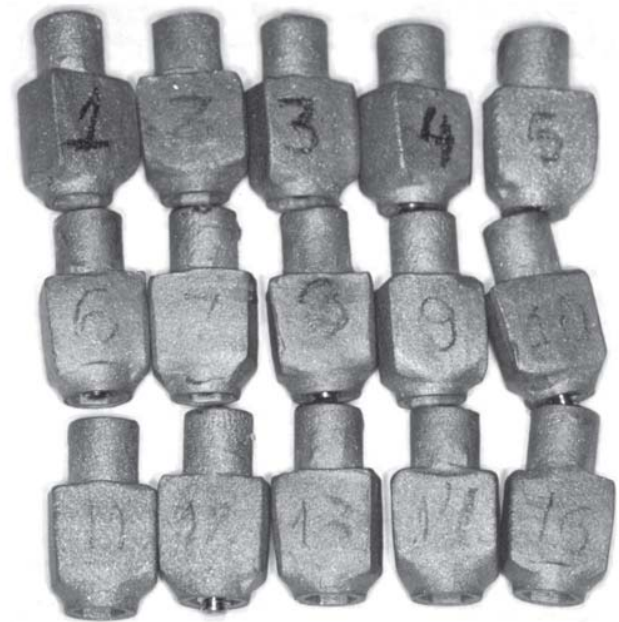

b

FIGURE 3- a- Laser welding group (LWG) and b-Casting group (CG) 


\section{RESULTS}

The means were obtained and an exploratory data analysis was performed to determine the most appropriate statistical test. The data obtained were submitted to statistical analysis (descriptive and inferential). The descriptive statistics data (ìm) for Control (mean \pm standart deviation: 13.50 \pm 21.80; median = 0,00), for Casting (36.20 \pm 12.60 ; median $=3.70)$, for Laser $(10.50 \pm 12.90$; median $=3.00)$ were submitted to Kruskal-Wallis ANOVA, $\alpha=5 \%$. and represented in Table 1 and Figure 4.

These tests indicated that distorsion (misadjust) median values represented by gaps differ statistically $(\mathrm{Kw}=17.40$; $\mathrm{df}=2 ; \mathrm{p}=0.001<0.05)$ and Dunn's $(5 \%)$ test show difference between Casting and the two others.

\section{DISCUSSION}

The importance of the passive fitting of the prosthodontics over osseointegrated implants has been described in the literature by many authors ${ }^{7,10,6}$

The passive adaptation refers to the union between the prosthodontical structure and the implant platform when UCLA abutments directly are connected to these. What is wanted is a relation of maximum contact between them without the induction of tension ${ }^{5,11}$. Through scanning electron microscopy (SEM) this adaptation can be analyzed, if it is perfect or if there are gaps between the prosthodontical piece and the abutment. This work measured the existent spaces between the casting and the implant with a measurement microscope.

The absence of passive adaptation may cause problems in the adjacent biological structures, loosen of the screws, mobility due to transverse stress; and when there is an excessive repeated tighten of the screws, fatigue can occur and take to a fracture of the implant components ${ }^{2,5,9,10}$.

In this study, the measurements of the gaps in the junction between the coping and the implant platform, to casting group (CG) were significantly bigger than the ones of the laser welding group (LWG). It can be recommended

TABLE 1- Mean values, standard deviation, variation coefficient, minimum value, median and maximum value for the 3 studied group $(\mu \mathrm{m})$

\begin{tabular}{llll}
\hline Groups & Control & Casting & Laser \\
\hline $\mathrm{N}$ & 15 & 15 & 15 \\
Mean & 13,50 & 36,20 & 10,50 \\
Standard deviation & 21,80 & 12,60 & 12,90 \\
Variance coeficient & 161.79 & 34.758 & 123.15 \\
Minimum & 0.00 & 18,00 & 0.00 \\
Median & 0.00 & 037,00 & 30,00 \\
Maximum & 70,00 & 59,00 & 39,00 \\
\hline
\end{tabular}

the use of the machined components over osseointegrated implants due to its more predictable fitting and contact. ${ }^{6}$

Our results demonstrated that the UCLA machined components adaptation was kept even before having its borders laser welded to a coping that was casted separatedly (LWG). In both groups (LWG and CG), it is relevant to consider the dimensional alterations which are a direct consequence of the casting process. During the procedures of the casting, more specifically during the cooling there is a contraction. In the casting group (CG), wax copings are totally substituted by metal with the calcinable UCLA component, probably it can be caused a biggest distorsion.

Carvalho, et al. ${ }^{4}$ (2002) evaluated the placing of the prosthodontical components Gold UCLA-type (CG) to the implant platform and UCLA-type (teflon) cast in an titaniumnickel-chromium alloy and in cp titanium. 10 prosthodontical components UCLA-type calcinatable, with hexagon, where used and distributed into 2 groups. The "T" group is composed of 5 UCLA cast in titanium cp which were connected to the implant (torque of 10 N.cm) and after were observed at the measurement microscope, similar to the one performed in this research. For this "T" group, the authors got a mean of unfitting of $24,133 \mu \mathrm{m}$ and in our study we got a mean of unfitting of $36.20 \mu \mathrm{m}$, a larger mean, but it should be considered that the number of samples was 3 times bigger than this. Besides, the samples made here received a standard waxing to simulate a clinical situation and in the study mentioned before, the 5 UCLA used didn't receive any layer of wax, being cast in the form of the abutment given by the manufacturer. Another factor to be observed is that the UCLA abutments used in these 2 studies are from different manufacturers.

Riedy, et al. ${ }^{12}$ compared two techniques used in the union of implant components in multiple prosthodontics: laser welding and single block casting. The laser welded components showed a better adaptation when compared to the ones cast in a single block. However, this result may not be compared to this study as they worked with many units of implants and observed horizontal misalignment while we used a single implant and observed vertical misalignment.

In this study, through the use of laser welding technique

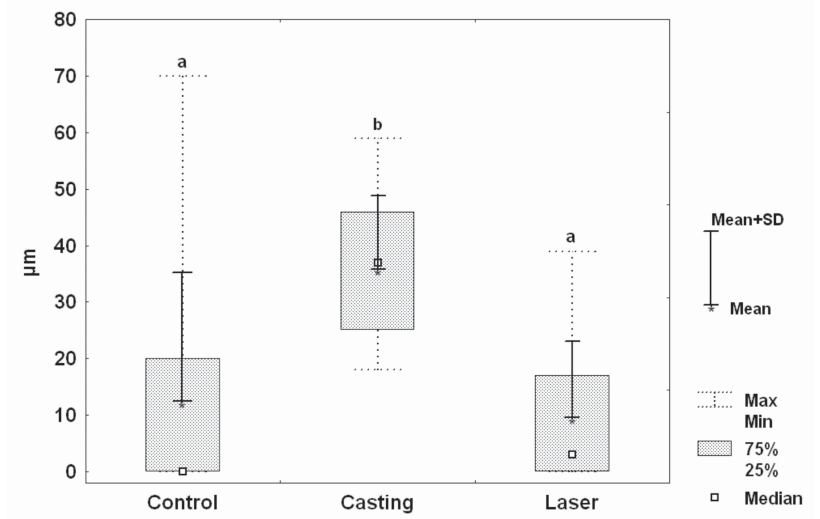

FIGURE 4- Box-plot and means, standard deviation for gap data $(\mu \mathrm{m})$. Set data followed by different letters correspond to statistically different groups (Dunn test, $\alpha=5 \%$ ) 
the unfitting was less than $25 \mathrm{um}$. In a single prosthodontic to link the cast coping to the border of the titanium machined abutment . According to the results here achieved, this welding didn't modify the adaptation of the abutment to the implant platform as there was no significant difference between the laser welding group (LWG) and the control group (CTRLG).

The use of laser in the welding of titanium pieces presents the following advantages: hitting specifical points (the heat exposure is smaller than a contact with a flame); the process takes less time and it's not necessary to use a different material as a welding intermediate, that is, the resistance improves ${ }^{16}$.

\section{CONCLUSIONS}

With the results of the gap measurements on the copingimplant platform interface, on the y axis, obtained by casting of UCLA teflon abutments (CG) and copings cast in titanium and laser welded on the upper and lower border of titanium shaped UCLA abutments (LWG), we concluded:

1-The smaller values of non adaptation were obtained for the laser welding group (LWG) statistically different from the casting group (CG).

2-The casting group (CG) had the worst result statistically significant, when compared to the other groups: laser welding group (LWG) and control group (CTRLG).

3-The laser welding group (LWG) didn't show statistically significant difference when compared to the control group (CTRLG).

\section{ACKNOWLEGMENTS}

Thanks to Conexão (Sistemas de Próteses, Brasil) for supply the components for the research.

FAPESP Process cientific n ${ }^{\circ} 02 / 14066-9$

To professor Ivan Balducci for acomplishing the statistical analysis.

To professor Dr. Celia Maria Rizzatti Barboza for the use of the measurement microscope - Fapesp process n. 98/ 01705-6.

To the technician Juiliana Martins Rossi from Laboratório Vaiazzi for the help on the prosthodontical work.

\section{REFERENCES}

1- Berg E, Wagner WC, Davik G, Dootz ER. Mechanical properties of laser-welded cast and wrought titanium. J Prosthet Dent 1995;74:250-57.

2- Beumer J, Lewis SG. Sistema de implantes Branemark procedimentos clínicos e laboratoriais. São Paulo: Pancast; 1996. p. $1-15$.
3- Costa EMV. Avaliação da distorção linear em estruturas metálicas de próteses sobre implantes: fundidas em uma peça e em segmentos soldados a laser e através da soldagem convenciona (brasagem). São José dos Campos; 2001. 81p. Dissertação (Mestrado em Prótese Parcial Fixa) - Faculdade de Odontologia UNESP-FOSJC.

4- Carvalho MCA, Bondioli IR, Costa EMV, Nishioka RS, Bottino MA, Neisser MP. Avaliação microscópica entre a adaptação dos pilares gold UCLA à plataforma do implante e UCLA de teflon fundidos em titânio e liga de níquel-crômio-titânio.Estudo in vitro. BCL 2002;34:105-10.

5- Cordioli G, Castagna S, Consolati E. Single-tooth implant rehabilitation: a retrospective study of 67 implants. Int J. Prosthodont 1994; $7: 525-31$.

6- Dinato JC, Polido WD. Implantes osseointegrados: cirurgia e prótese. São Paulo, Artes Médicas, 2001, p. 139-167; 283-315; 46577.

7- Goll G. Production of accurately fitting full-arch implant frameworks: part I - clinical procedures. J Prosthet Dent 1991;66:377-84.

8- Jemt T, Pettersson P. A 3-year follow-up study on single implant treatment. J Dent 1993; 21:203-8.

9- Lindhe J. Tratado de periodontia clínica e implantologia oral. Rio de Janeiro, Editora Guanabara Koogan; 1999. p. 623-9.

10- Misch CE. Implante odontológico contemporâneo, São Paulo, Pancast; 1996. p. 678-705; 281-315.

11- Neves JB. Implantodontia oral: otimização da estética - uma abordagem de tecidos mole e duro. Belo Horizonte, Roma Editora; 2001. p. 335-49.

12- Riedy SJ, Lang BR, Lang BE. Fit of implant frameworks fabricated by different techniques. J Prosthet Dent 1997;78:596-604.

13- Sakaguchi RL, Borgersen SE. Nonlinear finite element contact analysis of dental implant components. Int J Oral Maxillofac Implants 1993;8:655-61.

14- Waskewicz GA, Ostrowski JS, Parks VJ. Photoelastic analysis of stress distribution transmitted from a fixed prosthesis attached to osseointegrated implants. Int J Oral Maxillofac Implants 1994; 9:405-11.

15- Wee AG, Aquilino SA, Schneider RL. Strategies to achieve fit in implant prosthodontics: a review of the literature. Int J Prosthodont 1999;12:167-78.

16- Yamagishi T, Ito M, Fujimura M. Mechanical properties of laser welds of titanium in dentistry by pulsed Nd:YAG laser apparatus. J Prosthet Dent 1993;70:264-73. 